\title{
Tinjauan Kebijakan Pengelolaan Limbah Medis Infeksius Penanganan Corona Virus Disease 2019 (Covid-19)
}

\author{
Candra Nugraha \\ Program Studi Teknik Lingkungan - Institut Teknologi Nasional Bandung \\ Email: candranugraha@itenas.ac.id
}

\begin{abstract}
Abstrak
Satu aspek penting dalam penangan wabah Corona Virus Disease 2019 (Covid-19) adalah penangangan limbah medis yang dihasilkan, baik dari pasien maupun petugas medis. Pemerintah pusat dan Pemerintah Daerah Provinsi Jawa Barat telah mengeluarkan kebijakankebijakan terkait pengelolaan limbah medis infeksius yang berasal dari fasilitas pelayanan kesehatan, rumah sakit darurat, maupun rumah karantina/isolasi mandiri.

Terdapat 5 (lima) kebijakan dari pemerintah pusat dan 2 (dua) kebijakan Pemerintah Provinsi Jawa Barat yang ditinjau berdasarkan tahapan pengelolaan limbah B3. Hasil tinjauan menujukkan bahwa, meskipun kebijakan dikeluarkan tidak secara terpadu, namun tahapan pengelolaan limbah medis infeksius telah ditetapkan dengan cukup jelas dan dapat dijadikan sebagai acuan. Acuan ini sangat penting untuk pelaksanaan pengelolaan limbah medis infeksius pada masa darurat sekarang ini, untuk menghindari terjadinya penyebaran virus melalui media limbah medis.
\end{abstract}

Kata kunci: kebijakan, pengelolaan limbah B3, limbah medis infeksius, Covid-19

\section{Abstract}

An important aspect in managing Corona Virus Disease 2019 (Covid-19) outbreak is handling of generated-medical wastes, both from the patient and medical personnels. The central government and the Provincial Government of West Java have issued policies related to infectious medical waste management originating from health services facilities, emergency hospital, as well as self-quarantine/isolation houses.

There are 5 (five) policies from central government and 2 (two) policies from Provincial Government of West Java which are reviewed based on the steps of toxic and hazardous waste management. The results of review show that, although the policies were not issued in an integrated manner, but the steps of infectious medical waste management have been established quite clearly and can be used as a reference. This reference is very important for implementation of infectious medical waste management in this current emergency situation, to avoid the virus spreading through the medical waste as the media.

Keywords : policy, toxic and hazardous waste management, infectious medical waste, Covid19)

\section{PENDAHULUAN}

Seperti kita ketahui bersama, seluruh dunia saat ini sedang berupaya untuk menangani wabah Corona Virus Disease (Covid-19), termasuk Indonesia. Satu aspek penting yang tidak boleh dilupakan dalam penangan wabah ini adalah penanganan limbah medis dengan karakter infeksius, yang dihasilkan dari pasien dan petugas medis yang terpapar dengan virus tersebut saat

http://ejournal.urindo.ac.id/index.php/jukmas

Article History : 
penanganan pasien. Penanganan limbah infeksius ini menjadi penting, karena dikhawatirkan limbah ini bisa menjadi salah satu media penyebaran virus apabila tidak ditangani dengan baik. Di seluruh dunia, diperkirakan sedikitnya $5 \cdot 2$ juta orang, termasuk 4 juta anak-anak, meninggal setiap tahun karena penyakit yang berkaitan dengan limbah medis yang tidak terkelola dengan baik [1].

Mengingat penularan penyakit sindrom pernapasan akut coronavirus 2 (SARS-CoV2) secara global, limbah biomedis yang berlebihan telah menjadi ancaman besar baru bagi kesehatan masyarakat dan lingkungan[2]. Penanganan limbah rumah sakit yang tidak tepat dapat memperburuk penyebaran SARS-CoV-2 ke staf medis dan orang yang menangani limbah Terlebih lagi, dengan adanya wabah ini, volume timbulan limbah medis meningkat cukup signifikan.

Berdasarkan data dari Kementerian Ekologi dan Lingkungan China, hingga 21 Maret 2020, terjadi penambahan limbah medis dari $4.902,8$ ton per hari menjadi 6.066 ton per hari[3]. Data dari RSPI Sulianto Suroso menunjukkan adanya kenaikan timbulan limbah medis dan alat pelindung diri (APD) yang dimusnahkan oleh insinerator. Pada Januari 2020, jumlah timbulan adalah 2.750 $\mathrm{kg}$, meningkat menjadi $4.500 \mathrm{~kg}$ pada bulan Maret 2020, seiring dengan peningkatan pasien Covid-19 yang dirawat di rumah sakit tersebut [4].

Prinsip pencegahan penularan penyakit infeksi adalah melalui pemutusan rantai host/pejamu/ inang. Oleh karena itu, dalam menyikapi wabah Covid-19 ini, Perhimpunan Dokter Spesialis Penyakit Dalam Indonesia (PAPDI) merekomendasikan memutuskan rantai host/pejamu/inang dengan berbagai cara. Pemutusan mata rantai penyebaran virus bisa dilakukan salah satunya dengan pengelolaan limbah medis infeksius dengan benar sesuai prosedur. Secara khusus, pengelolaan limbah medis diatur dalam PermenLHK No. P.56/Menlhk-Setjen/2015 tentang Tata Cara dan Persyaratan Teknis Pengelolaan Limbah B3 dari Fasilitas Pelayanan Kesehatan[5].

Tinjauan ini mengulas kebijakan pemerintah pusat dan Pemerintah Provinsi Jawa Barat terkait dengan penanganan limbah medis infeksius, mulai dari tahap pemilahan hingga pemusnahan/penimbunan akhir.

\section{METODE PENELITIAN}

Penelitian ini merupakan policy study yang ditujukan untuk mengalasis pelaksanaan penanggulaangan limbah medis selama Pandemi Covid-19. 


\section{Ruang Lingkup dan Pendekatan}

\subsection{Ruang lingkup}

Seiring dengan kondisi pandemi Covid-19 yang sedang terjadi saat ini, fokus tinjauan ini adalah pada kebijakan penanganan limbah medis dengan karakter infeksius. Mengacu pada PermenLHK No. P.56/Menlhk-Setjen/2015, limbah infeksius adalah "limbah yang terkontaminasi organisme patogen yang tidak secara rutin ada di lingkungan dan organisme tersebut dalam jumlah dan virulensi yang cukup untuk menularkan penyakit pada manusia rentan". Secara umum, limbah medis infeksius ini dikategorikan sebagai Limbah Bahan Berbahaya dan Beracun (limbah B3)[6].

Dalam tinjauan ini, limbah medis infeksius adalah yang limbah yang dihasilkan dari fasilitas pelayanan kesehatan (fasyankes), yang meliputi pusat kesehatan masyarakat, klinik pelayanan kesehatan atau sejenis, dan rumah sakit. Selain itu, tinjauan ini juga melingkupi limbah medis infeksius yang berasal dari rumah sakit darurat Covid-19 yang ditetapkan pemerintah, dan rumah tangga dimana terdapat pasien dengan status Orang Dalam Pemantauan (ODP) atau Pasien Dalam Pengawasan (PDP) yang melakukan karantina/isolasi mandiri.
Terkait dengan tata kelola, tinjauan ini melingkupi tahapan pengelolaan limbah B3 secara umum yang meliputi tahapan pengurangan dan pemilahan, penyimpanan, pengangkutan, pengolahan, dan/atau penimbunan limbah B3.

\subsection{Pendekatan}

Tinjauan kebijakan ini dilakukan melalui penelaahan terhadap kebijakan khusus yang dikeluarkan pada masa pandemi Covid-19 ini, baik yang secara langsung maupun tidak langsung berkaitan dengan pengelolaan limbah medis infeksius. Tinjauan dilakukan terhadap seluruh kebijakan yang telah dikeluarkan oleh pemerintah pusat dan pemerintah Provinsi Jawa Barat sampai dengan tanggal 17 April 2020.

\section{KEBIJAKAN PENGELOLAAN}

\subsection{Kebijakan khusus}

Pemerintah, sesuai kewenangannya masingmasing, secara khusus telah mengeluarkan beberapa kebijakan sebagai acuan pengelolaan limbah medis infeksius penanganan Covid-19. Kebijakan ini merupakan turunan dari peraturan yang sebelumnya telah ada, yaitu Peraturan Pemerintah Nomor 101 Tahun 2014 tentang Pengelolaan Limbah Bahan Berbahaya dan Beracun, dan Peraturan Menteri Lingkungan Hidup dan Kehutanan Nomor P.56/Menlhk-Setjen/2015 Tahun 2015 
tentang Tata Cara Pengelolaan Limbah B3 dari Fasilitas Pelayanan Kesehatan.

Kebijakan khusus pemerintah pusat dan Pemerintah Provinsi Jawa Barat yang dikaji dalam tulisan ini, diurutkan sesuai dengan tanggal keluarnya kebijakan tersebut, adalah sebagai berikut:

1. Surat Kepala Dinas Kesehatan Provinsi Jawa Barat No. 443.5/2084/Kesmas tentang Kewaspadaan Pengelolaan Limbah Medis di Fasyankes pada Kondisi Pandemi Corona Virus Disease 2019 (Covid-19), tanggal 19 Maret 2020, ditujukan kepada Kepala Dinas Kesehatan Kab./Kota se-Jawa Barat.

2. Surat Mentri Lingkungan Hidup \& Kehutanan

\section{S.167/MENLHK/PSLB3/PLB.3/3/2020}

tentang Limbah B3 Medis pada Fasilitas Pelayanan Kesehatan Darurat Covid-19, tanggal 22 Maret 2020, ditujukan kepada Kepala BNPB/Ketua Gugus Tugas Percepatanan Penanganan Covid19.

3. Surat Edaran MenLHK No. SE.2/MENLHK/PSLB3.3/3/2020 tentang Pengelolaan Limbah Infeksius (Limbah B3) dan Sampah Rumah Tangga Dari Penanganan Corona Virus Disease (Covid-19), tanggal 24 Maret 2020, ditujukan kepada Kepala BNPB/Ketua Gugus Tugas Percepatanan Penanganan
Covid-19, Gubernur/Bupati/Walikota seluruh Indonesia.

4. Surat Edaran Kepala Dinas Lingkungan Hidup Provinsi Jawa Barat No. 658/1545/BD II/2020, tanggal 27 Maret 2020, ditujukan kepada Kepala Instansi Lingkungan Hidup Se-Jawa Barat.

5. SE Mendagri No. 440/2622/SJ Tentang Pembentukan Gugus Tugas Percepatan Penanganan Corona Virus Disease 2019 (Covid-19) Daerah, tanggal 29 Maret 2020, ditujukan kepada Gubernur/Bupati/Walikota di seluruh Indonesia.

6. Surat Dirjen PSLB3 KLHK No. S.156/PSLB3/PKPLB3/PLB.2/3/2020 tentang Pengelolaan Limbah B3 Masa Darurat Penanganan Corona Virus Disease-19, tanggal 30 Maret 2020, ditujukan kepada Pimpinan Perusahaan Pengelola dan Pengangkut Limbah B3 Infeksius.

7. Peraturan Menteri Kesehatan No. 9 tahun 2020 tentang Pedoman Pembatasan Sosial Berskala Besar Dalam Rangka Percepatan Penanganan Corona Virus Disease 2019 (Covid-19), tanggal 3 April 2020.

\subsection{Tinjauan kebijakan pengelolaan limbah} medis infeksius

\subsubsection{Identifikasi limbah}


Mengacu pada Surat Edaran MenLHK No. SE.2/MENLHK/PSLB3.3/3/2020, dinyatakan bahwa alat dan sampel laboratorium yang telah digunakan merupakan Limbah B3 berupa limbah infeksius (A337-1), sehingga perlu dikelola sebagai Limbah B3, sekaligus untuk mengendalikan, mencegah dan memutus penularan Covid-19 serta menghindari terjadinya penumpukan limbah yang ditimbulkan dari penanganan Covid-19.

Selanjutnya, mengacu pada Surat Kadinkes Prov. Jawa Barat No. 443.5/ 2084/Kesmas, karakteristik limbah yang berpotensi dihasilkan dalam penanganan Covid-19 meliputi infeksius, tajam, patologis, dan farmasi. Prinsip penanganan limbah terkait Covid-19 adalah precautionary (melindungi risiko pada petugas pengelola limbah) dan proximity principles (prinsip kedekatan dalam penanganan limbah untuk meminimalkan risiko pada pemindahan).

Pada tahap identifikasi ini, sudah cukup jelas disebutkan contoh jenis limbah medis infeksius yang harus dikelola. Namun demikian, perlu adanya pernyataan tambahan bahwa peralatan lain yang terkontaminasi limbah medis akan dianggap sebagai limbah medis sehingga perlu penanganan yang sama. Hal ini berlaku misalnya untuk Alat Pelindung Diri (APD) petugas medis yang kontak langsung dengan pasien, yang telah digunakan dan tidak akan digunakan lagi yang dimungkinkan terkontaminasi. Meningkatnya volume timbulan limbah medis infeksius salah satunya berasal dari APD ini, sehingga perlu diantisipasi pada proses pengelolaan selanjutnya.

\subsubsection{Penyimpanan, pengangkutan, dan} pemusnahan limbah medis infeksius dari fasyankes

Fasilitas pelayanan kesehatan (fasyankes) dalam hal ini meliputi pusat kesehatan masyarakat, klinik pelayanan kesehatan atau sejenis, dan rumah sakit. Mengacu pada Surat Edaran MenLHK No. SE.2/MENLHK/PSLB3.3/3/2020, hal yang perlu dilakukan terhadap limbah medis infeksius yang berasal dari fasilitas pelayanan kesehatan adalah:

a. Melakukan penyimpanan limbah infeksius dalam kemasan yang tertutup paling lama 2 (dua) hari sejak dihasilkan;

b. Mengangkut dan/atau memusnahkan pada pengolahan Limbah B3:

1) fasilitas insinerator dengan suhu pembakaran minimal $800^{\circ} \mathrm{C}$; atau

2) autoclave yang dilengkapi dengan pencacah (shredder); 
c. Residu hasil pembakaran atau cacahan hasil autoclave dikemas dan dilekati simbol "Beracun" dan label Limbah B3 yang selanjutnya disimpan di Tempat Penyimpanan Sementara Limbah B3 untuk selanjutnya diserahkan kepada pengelola Limbah B3.

Mengacu pada Surat Kadinkes Prov. Jawa Barat No. 443.5/2084/Kesmas, secara khusus dinyatakan bahwa limbah harus segara dibuang, dengan acuan waktu 2 hari atau ketika wadah limbah sudah mencapai $3 / 4$ kapasitasnya.

Pada tahap ini, hal yang harus menjadi perhatian adalah ketersediaan teknologi pemusnah limbah medis infeksius seperti yang disebutkan diatas beserta izin operasionalnya dari KLHK. Sebagai contoh, untuk Provinsi Jawa Barat saat ini ditetapkan sebanyak 105 rumah sakit rujukan Covid-19. Namun demikian, hanya 5 rumah sakit rujukan yang telah memiliki izin pengolahan limbah medis .

3.2.3 Penyimpanan, pengangkutan, dan pemusnahan limbah medis infeksius dari Fasyankes darurat Covid-19

Untuk fasyankes darurat Covid-19, seperti misalnya Wisma Atlet atau fasilitas sejenis lainnya yang akan digunakan, mengacu pada Surat MenLHK No. 5.167
/MENLHK/PSLB3/PLB.3/3/2020,

pengelolaan limbah infeksius mengacu pada prosedur-prosedur yang meliputi tahapantahapan:

1. Identifikasi, pemilahan dan pewadahan: Setiap penghasil limbah wajib melakukan identifikasi untuk semua limbah yang dihasilkannya. Melakukan pemilahan dan pengemasan LB3 berdasarkan karakter: infeksius, patologis, bahan kimia dan farmasi kadaluarsa, tumpahan atau sisa kemasan.

2. Penyimpanan Limbah: Penyimpanan dilakukan sesuai karakter dan pengemasan. • Khusus limbah infeksius disimpan paling lama: 2 (dua) hari hingga dimusnahkan, apabila pada suhu kamar. 90 (sembilan puluh) hari hingga dimusnahkan apabila pada suhu $0^{\circ} \mathrm{C}$.

3. Pemusnahan: Pemusnahan dengan pembakaran menggunakan incinerator yang dioperasionalkan Fasyankes atau pihak jasa pengolah limbah medis berizin. Insinerator memiliki ruang bakar dengan suhu minimal $800^{\circ} \mathrm{C}$.

Sama halnya dengan fasyankes pada umumnya, pengelolaan limbah medis dari fasyankes darurat juga harus memenuhi ketentuan teknis yang sama. Kendala utama yang dihadapi oleh fasyankes darurat ini 
adalah ketersediaan alat pengolah dan/atau pemenuhan persyaratan teknis unit pengolah, seperti temperatur pembakaran minimal. Oleh karena kendala tersebut, pengelolaan limbah medis infeksius dari fasyankes darurat ini harus dilakukan melalui pihak jasa pengolah limbah medis berizin.

\subsubsection{Penyimpanan, pengangkutan, dan} pemusnahan limbah medis infeksius dari rumah karantina/isolasi mandiri

Mengacu pada Surat Edaran MenLHK No. SE.2/MENLHK/PSLB3.3/3/2020, pengelolaan limbah infeksius yang berasal dari rumah tangga yang terdapat ODP (Orang Dalam Pemantauan) adalah melalui tahapan pengumpulkan limbah infeksius berupa limbah APD antara lain berupa masker, sarung tangan, dan baju pelindung diri; dan pengemasan tersendiri dengan menggunakan wadah tertutup, dapat berupa plastik terikat, untuk selanjutya diangkut dan dimusnahkan di pengolahan limbah B3. Dan mengacu pada SE Mendagri No. 440/2622/SJ, pembuangan harus dibungkus rapi dan dilakukan setiap hari.

Selanjutnya dinyatakan bahwa petugas dari dinas yang bertanggungjawab di bidang lingkungan hidup, kebersihan dan kesehatan melakukan pengambilan dari setiap sumber untuk diangkut ke lokasi pengumpulan yang telah ditentukan sebelum diserahkan ke pengolah limbah B3. Seluruh petugas kebersihan atau pengangkut sampah wajib dilengkapi dengan APD khususnya masker, sarung tangan dan safety shoes yang setiap hari harus disucihamakan.

Terkait dengan fasilitas pengolahan, mengacu pada Surat Edaran Kepala Dinas Lingkungan Hidup Provinsi Jawa Barat No. 658/1545/BD II/2020, limbah medis infeksius yang terkumpul ini perlu dikelola lebih lanjut salah satunya dengan menyertakan pada pengelolaan di fasyankes yang telah berjalan.

Pada tahap pengumpulan limbah, mengingat lokasi dari ODP (dan juga PDP yang karantina/isolasi mandiri) yang tidak terpetakan secara resmi dan jelas, teknis pengumpulan limbah medis infeksius oleh petugas dari dinas yang bertanggungjawab juga menjadi tidak jelas. Ketidakjelasan ini menyebabkan limbah medis tersebut dapat berpotensi tercampur dengan limbah domestik rumah tanggal lainnya sehingga tidak terkelola sebagaimana mestinya. Selain itu, pada prakteknya, pengumpulan sampah dari rumah tangga tidak selalu dilakukan tidak petugas dinas, dan tidak juga dilengkapi dengan APD khusus yang memadai, sehingga berpotensi terjadi penularan ke petugas sampah. Oleh karena 
itu, perlu terobosan lain, seperti misalnya yang dilakukan oleh Pemerintah Provinsi Jawa Barat dengan sosialisasi pemilahan dan pengemasan limbah medis dalam kemasan terpisah dan tertutup rapat, menyimpannya selama 7 hari, sebelum diserahkan pada petugas pengumpul sampah .

\subsubsection{Pengelolaan limbah kegiatan pemulasaraan jenazah}

Majelis Ulama Indonesia telah mengeluarkan Fatwa MUI No. 18 Tahun 2020 tentang Pedoman Pengurusan Jenazah (Tajhiz al-jana'iz) muslim yang terinfeksi Covid-19 (bagi yang beragama Islam). Untuk melengkapi fatwa tersebut, maka perlu ditetapkan juga pengelolaan limbah medis infeksius dari kegiatan tersebut.

Pengelolaan limbah infeksius dari pemulasaraan jenazah, apabila dilakukan di fasyankes, maka mengacu pada bagian 3.2.2 atau 3.2.3 diatas. Dan apabila pemulasaraan dilakukan di lokasi dimana karantina/isolasi mandiri dilakukan, maka pengelolaan limbah infeksius mengacu pada bagian 3.2.4 diatas.

\subsubsection{Pengangkutan dan pemusnahan limbah medis infeksius}

Mengacu pada Surat Dirjen PSLB3 KLHK No. S.156/PSLB3/PKPLB3/PLB.2/3/2020, setiap perusahaan pengangkut dan pengolah diminta untuk melakukan kegiatan sebagai berikut:

1. Mengangkut dan memusnahkan limbah infeksius sesegara mungkin;

2. menerima limbah B3 infeksius dari Fasilitas Pelayanan Kesehatan (fasyankes) sesuai ketentuan izin/rekomendasi;

3. Agar tetap mengoptimalkan operasional pemusnahan limbah yang bersifat infeksius tanpa dibuka kemasannya;

4. melakukan pencatatan dan pelaporan kegiatan pengolahan limbah B3 infeksius masa penanganan darurat; dan

5. melaksanakan prosedur keselamatan dan kesehatan kerja (K3) sesuai ketentuan peraturan perundangundangan.

Terkait dengan kegiatan pengangkutan limbah medis, dengan memperhatikan Peraturan Menteri Kesehatan No. 9/2020 pasal 13 ayat 10 perihal pembatasan moda transportasi, pengangkutan limbah medis infeksius perlu dinyatakan secara tegas oleh pihak yang berwenang sebagai transportasi barang yang dikecualikan dalam pembatasan moda transportasi. Pengangkutan limbah medis ini, sama halnya dengan obat-obatan dan kelengkapan medis lainnya, merupakan 
salah satu cara pemenuhan kebutuhan dasar penduduk, yaitu kesehatan dan sanitasi.

Selanjutnya mengenai pemusnahan limbah medis, saat ini terdapat 14 perusahaan penyedia jasa pengolahan limbah medis, dimana 6 perusahaan berada di Provinsi Jawa Barat dan 2 di Provinsi Banten. Dengan terkonsentrasinya fasilitas ini pada dua provinsi tersebut, maka perlu dipertimbangkan langkah strategis yang bisa mengefisienkan pengangkutan dan pemusnahan limbah medis infeksius yang berasal dari provinsi atau pulau lain. Selain itu, perhitungan total kapasitas pemusnahan limbah medis dari keseluruhan perusahaan juga menjadi hal yang penting agar timbulan limbah medis, khususnya yang bersifat infeksius, dapat segera dimusnahkan.

Tabel.1 Tahapan pengelolaan limbah medis infeksius beserta acuan kebijakannya

\begin{tabular}{|c|c|c|c|}
\hline No & Tahap pengelolaan & Aspek penting & $\begin{array}{c}\text { Acuan } \\
\text { kebijakan }\end{array}$ \\
\hline \multirow[t]{2}{*}{1} & \multirow[t]{2}{*}{ Identifikasi limbah } & $\begin{array}{l}\text { Alat dan sampel laboratorium } \\
\text { merupakan limbah infeksius (A337- } \\
\text { 1) }\end{array}$ & $\begin{array}{l}\text { Surat Edaran } \\
\text { MenLHK No. } \\
\text { SE.2/MENLHK/PS } \\
\text { LB3.3/3/2020 } \\
\end{array}$ \\
\hline & & $\begin{array}{l}\text { Karakteristik limbah yang } \\
\text { berpotensi dihasilkan meliputi } \\
\text { infeksius, tajam, patologis, dan } \\
\text { farmasi }\end{array}$ & $\begin{array}{l}\text { Surat Kadinkes } \\
\text { Prov. Jawa Barat } \\
\text { No. 443.5/ } \\
\text { 2084/Kesmas, }\end{array}$ \\
\hline 2 & Pemilahan & $\begin{array}{l}\text { Pemilahan dan pengemasan LB3 } \\
\text { berdasarkan karakter: infeksius, } \\
\text { patologis, bahan kimia dan farmasi } \\
\text { kadaluarsa, tumpahan atau sisa } \\
\text { kemasan. }\end{array}$ & $\begin{array}{l}\text { Surat MenLHK } \\
\text { No. s.167 } \\
\text { /MENLHK/PSLB3/ } \\
\text { PLB.3/3/2020 }\end{array}$ \\
\hline \multirow[t]{2}{*}{3} & \multirow[t]{2}{*}{ Pengemasan } & $\begin{array}{l}\text { Limbah infeksius dalam kemasan } \\
\text { yang tertutup paling lama } 2 \text { (dua) } \\
\text { hari sejak dihasilkan, }\end{array}$ & $\begin{array}{l}\text { Surat Edaran } \\
\text { MenLHK No. } \\
\text { SE.2/MENLHK/PS } \\
\text { LB3.3/3/2020 } \\
\end{array}$ \\
\hline & & $\begin{array}{l}\text { atau ketika wadah limbah sudah } \\
\text { mencapai } 3 / 4 \text { kapasitasnya. }\end{array}$ & $\begin{array}{l}\text { Surat Kadinkes } \\
\text { Prov. Jawa Barat } \\
\text { No. } \\
443.5 / 2084 / \text { Kesm } \\
\text { as }\end{array}$ \\
\hline 4 & Penyimpanan & $\begin{array}{l}\text { Penyimpanan dilakukan sesuai } \\
\text { karakter dan pengemasan. } \\
\text { Khusus limbah infeksius disimpan } \\
\text { paling lama: }\end{array}$ & $\begin{array}{l}\text { Surat MenLHK } \\
\text { No. s.167 } \\
\text { /MENLHK/PSLB3/ } \\
\text { PLB.3/3/2020 }\end{array}$ \\
\hline
\end{tabular}




\begin{tabular}{|c|c|c|c|}
\hline & & $\begin{array}{l}\text { - } 2 \text { (dua) hari hingga dimusnahkan, } \\
\text { apabila pada suhu kamar. } \\
\text { - } 90 \text { (sembilan puluh) hari hingga } \\
\text { dimusnahkan apabila pada suhu } \\
0^{\circ} \mathrm{C} \text {. }\end{array}$ & \\
\hline & & $\begin{array}{l}\text { Limbah medis dari rumah tangga: } \\
\text { limbah medis infeksius dikelola } \\
\text { salah satunya dengan menyertakan } \\
\text { pada pengelolaan di fasyankes yang } \\
\text { telah berjalan }\end{array}$ & $\begin{array}{l}\text { Surat Edaran } \\
\text { Kepala Dinas } \\
\text { Lingkungan Hidup } \\
\text { Provinsi Jawa } \\
\text { Barat No. } \\
658 / 1545 / \mathrm{BD} \\
\text { II/2020 }\end{array}$ \\
\hline \multirow[t]{2}{*}{4} & \multirow[t]{2}{*}{ Pengangkutan } & Pengangkutan sesegera mungkin & $\begin{array}{l}\text { Surat Dirjen } \\
\text { PSLB3 KLHK No. } \\
\text { S.156/PSLB3/ } \\
\text { PKPLB3/PLB.2/3/ } \\
2020\end{array}$ \\
\hline & & $\begin{array}{l}\text { Limbah medis sebagai barang } \\
\text { penting dan esensial sehingga } \\
\text { diperbolehkan beroperasi di } \\
\text { wilayah PSBB }\end{array}$ & PMK No. 9/2020 \\
\hline \multirow[t]{4}{*}{5} & \multirow[t]{3}{*}{ Pemusnahan } & $\begin{array}{l}\text { Pemusnahan sesegera mungkin dan } \\
\text { tanpa pembukaan kemasan }\end{array}$ & $\begin{array}{l}\text { Surat Dirjen } \\
\text { PSLB3 KLHK No. } \\
\text { S.156/PSLB3/ } \\
\text { PKPLB3/PLB.2/3/ } \\
2020\end{array}$ \\
\hline & & $\begin{array}{l}\text { Teknologi pemusnah: } \\
\text { 1) fasilitas insinerator dengan suhu } \\
\text { pembakaran minimal } 800^{\circ} \mathrm{C} \text {; } \\
\text { atau } \\
\text { 2) autoclave yang dilengkapi } \\
\text { dengan pencacah (shredder); }\end{array}$ & $\begin{array}{l}\text { Surat Edaran } \\
\text { MenLHK No. } \\
\text { SE.2/MENLHK/PS } \\
\text { LB3.3/3/2020 }\end{array}$ \\
\hline & & $\begin{array}{l}\text { Pemusnahan dengan pembakaran } \\
\text { menggunakan insinerator yang } \\
\text { dioperasionalkan fasyankes atau } \\
\text { pihak jasa pengolah limbah medis } \\
\text { berizin. } \\
\text { Insinerator memiliki ruang bakar } \\
\text { dengan suhu minimal } 800^{\circ} \mathrm{C} \text {. }\end{array}$ & $\begin{array}{l}\text { Surat MenLHK } \\
\text { No. s.167 } \\
\text { /MENLHK/PSLB3/ } \\
\text { PLB.3/3/2020 }\end{array}$ \\
\hline & Penimbunan & $\begin{array}{l}\text { Residu dikemas dan dilekati simbol } \\
\text { "Beracun" dan label Limbah B3 } \\
\text { yang selanjutnya disimpan di }\end{array}$ & $\begin{array}{l}\text { Surat Edaran } \\
\text { MenLHK No. } \\
\text { SE.2/MENLHK/PS } \\
\end{array}$ \\
\hline
\end{tabular}




\begin{tabular}{|l|l|l|l|}
\hline & $\begin{array}{l}\text { Tempat Penyimpanan Sementara } \\
\text { Limbah B3 untuk selanjutnya } \\
\text { diserahkan kepada pengelola } \\
\text { Limbah B3. }\end{array}$ & LB3.3/3/2020 \\
\hline
\end{tabular}

\section{SIMPULAN}

Berdasarkan tinjauan terhadap kebijakan yang telah dikeluarkan oleh pemerintah pusat dan Pemerintah Provinsi Jawa Barat sampai saat ini, beberapa catatan penting dan rekomendasi terkait pengelolaan limbah infeksius dari penanganan Covid-19 adalah sebagai berikut:

1. Kebijakan pemerintah terkait penanganan limbah medis infeksius secara umum telah mencakup hampir seluruh tahap pengelolaan limbah B3, yang dikeluarkan melalui beberapa surat/surat edaran secara terpisah.

2. Secara praktek saat ini, pemusnahan limbah infeksius dengan pembakaran menggunakan insinerator dilakukan bersamaan dengan limbah medis karakteristik lainnya (kecuali karakteristik radiokatif, peralatan medis dengan kandungan logam tinggi, tabung gas atau kontainer bertekanan)[7]. Dalam kondisi darurat dimana timbulan limbah medis sangat banyak, pemusnahan limbah infeksius dari penanganan Covid-19 harus menjadi prioritas.
3. Oleh karena itu, pemilahan limbah medis infeksius sejak dari tempat dihasilkan menjadi sangat penting untuk memastikan limbah tersebut dapat segera diangkut dan dimusnahkan, tanpa perlu lagi dilakukan pemilahan. Limbah medis yang berasal dari fasyankes dikemas dalam wadah standar (plastik kuning bertanda 'infeksius') untuk memudahkan penanganan lebih lanjut.

4. Limbah medis infeksius yang berasal dari rumah karantina/isolasi mandiri perlu didisinfeksi terlebih dahulu oleh ODP/PDP/keluarga dengan merendam atau menyemprot limbah dengan cairan mengandung disinfektan yang umum ada dipasaran, seperti bleaching atau pemutih pakaian, karbol, dll.), sebelum dikemas dalam kantong plastik terikat. Hal ini sebagai upaya pencegahan penularan, termasuk terhadap petugas yang bertanggungjawab melakukan pengambilan dan pengangkutan limbah. Untuk mencegah penyalahgunaan masker bekas, penting untuk merusak masker (misalnya dengan menggunting) sebelum dibuang. 
5. Tempat pengumpulan limbah medis infeksius yang berasal dari karantina/isolasi mandiri dapat menggunakan fasilitas yang ada di fasyankes terdekat (RS/Puskesmas/klinik). Jika tidak tersedia atau jarak terlalu jauh atau timbulan limbah sangat banyak dari suatu kawasan tertentu, maka tempat penyimpanan lain harus disiapkan oleh pemerintah daerah dengan minimal pemenuhan pada kriteria TPS LB3:

a. penyimpanan limbah infeksius dalam kemasan yang tertutup paling lama 2 (dua) hari sejak dihasilkan;

b. bangunan penyimpanan memiliki atap untuk menghindari hujan;

c. bangunan tidak berada di tempat pemukiman dengan kepadatan tinggi, untuk menghindari kekhawatiran masyarakat;

d. bangunan dapat menampung seluruh limbah infeksius yang dihasilkan;

e. bangunan terkunci untuk menghindari masuknya orang yang tidak berkepentingan atau binatang;

f. memiliki APD dan perlengkapan disinfeksi yang memadai; dan g. bangunan memiliki penanda sebagai tempat penyimpanan limbah infeksius sementara.

6. Pengangkutan limbah medis infeksius dari tempat penyimpanan limbah ke fasilitas pemusnah limbah harus menjadi prioritas. Sesuai peraturan, pengangkutan limbah dilakukan oleh penyedia jasa transportasi limbah medis yang telah memiliki izin dari pemerintah, dan ditunjuk oleh pemerintah untuk melakukan pengangkutan. Ketentuan terkait standar APD bagi pekerja berlaku untuk kegiatan ini. Dalam hal terjadi kondisi khusus dimana wilayah dibatasi akibat penerapan PSBB, transportasi limbah medis dikecualikan dari pembatasan. Dinas Kesehatan, Dinas Perhubungan, Kepolisian, dan pihak terkait lainnya, wajib menjamin transportasi limbah medis dapat dilakukan dengan lancar tanpa hambatan.

7. Sesuai peraturan, pemusnahan limbah medis infeksius dilakukan oleh pihak pemusnah limbah medis yang telah memiliki izin dari pemerintah, baik itu RS/fasyankes dan/atau perusahaan penyedia jasa pemusnahan limbah medis. Limbah dalam kantong plastik langsung dimusnahkan tanpa perlu adanya pembukaan/pemeriksaan isi. Pemusnahan dapat dilakukan dengan 
autoclave dan/atau insinerasi (pembakaran). Sisa pencacahan dan/atau pembakaran selanjutnya ditimbun di fasilitas penimbunan. Pemilihan teknologi dapat didasarkan pada ketersediaannya saat ini. Ketentuan terkait standar APD bagi pekerja berlaku untuk seluruh kegiatan ini.

8. Dalam hal terjadi kondisi khusus dimana proses pemusnahan melalui pembakaran menjadi prioritas dan harus bebas dari gangguan, pemerintah perlu melakukan upaya pengamanan yang memadai. Selain itu, dalam hal terjadi timbulan limbah medis infeksius yang melebihi kapasitas pemusnah yang tersedia saat ini, pemerintah perlu mempertimbangkan pemakaian fasilitas pembakaran yang tersedia di unit kegiatan lain (misalnya pabrik semen) sebagai upaya untuk memusnahkan limbah medis infeksius secara cepat.

9. Pengawasan terhadap pelaksanaan pengelolaan limbah medis infeksius, mulai dari pemilahan di penghasil, penyimpanan sementara, pengangkutan, dan pemusnahan, harus dilakukan secara menyeluruh dan menerus. Kendala atau kegagalan dalam pelaksanaan satu rantai proses tersebut perlu segera dievaluasi dan diperbaiki.
10. Berdasarkan kajian dari WHO, "there is no evidence that direct, unprotected human contact during the handling of health care waste has resulted in the transmission of the COVID-19 virus"[8], dengan catatan bahwa seluruh limbah dikumpulkan dalam wadah yang sesuai dan diolah/ditimbun dengan aman, baik di lokasi tempat penghasil maupun diluar. Selain itu, petugas pelaksana menggunakan APD (sepatu boots, apron, gaun lengan panjang, sarung tangan, masker, dan kacamata/pelindung wajah) yang memadai, dan melakukan pembersihan tangan setelah melepaskan perlengkapan tersebut.

11. Dengan mempertimbangkan kondisi perkembangan penanganan Covid-19, ketentuan lain diluar aturan tentang pengelolaan limbah infeksius yang berlaku saat ini memungkinkan untuk dikeluarkan oleh pemerintah sesuai kewenangannya, dengan tetap memperhatikan asas pengelolaan limbah B3 seperti precautionary (melindungi risiko pada petugas pengelola limbah) dan proximity principles (prinsip kedekatan dalam penanganan limbah untuk meminimalkan risiko pada pemindahan). 
DAFTAR PUSTAKA

[1] WHO. Health-care waste. Keyfact Health Care Waste, https://www.who.int/newsroom/fact-sheets/detail/health-carewaste (2018, accessed 8 June 2020).

[2] Peng J, Wu X, Wang R, et al. Medical waste management practice during the 2019-2020 novel coronavirus pandemic: Experience in a general hospital.

[3] Hatta RT. Perangi Corona COVID-19, Volume Limbah Medis di China Mencapai 182.000 Ton. Global, 25 March 2020, pp. 1-3.

[4] KLHK. Hasil pengolahan data yang berasal dari bahan presentasi Direktur Verifikasi Pengelolaan Limbah B3 dan Limbah Non B3, Dirjen PSLB3 - KLHK, pada Webinar Aspek Penting Pengelolaan Limbah Medis di Era Covid-19, diselenggarakan oleh Perhimpunan
Rumah Sakit Se.

[5] KLHK. Tata Cara dan Persyaratan Teknis Pengelolaan Limbah B3 dari Fasilitas Pelayanan Kesehatan. Indonesia: Kemetrian Lingkungan Hidup dan Kehutanan, 2015.

[6] KLHK. Peraturan Menteri Lingkungan Hidup dan Kehutanan Nomor: P.56/Menlhk- Setjen/2015 Tentang Tata Cara Persyaratan Teknis Pengelolaan Limbah Bahan Berbahaya dan Beracun dari Fasilitas Pelayanan Kesehatan. PermenLHK No. P.56/Menlhk-Setjen/2015, Kemetrian Lingkungan Hidup dan Kehutanan, 2015.

[7] Ilyas S, Ranjan R, Kim H. Disinfection technology and strategies for COVID19 hospital and bio-medical waste management.

[8] WHO WHO. Improvement of health through safe and environmentally sound waste management. 2010. 